\title{
Auschwitz. No hace mucho. No muy lejos Centro de Exposiciones Arte Canal
}

\author{
María De Mária Campos \\ Investigadora independiente, México \\ mariademariac@gmail.com
}

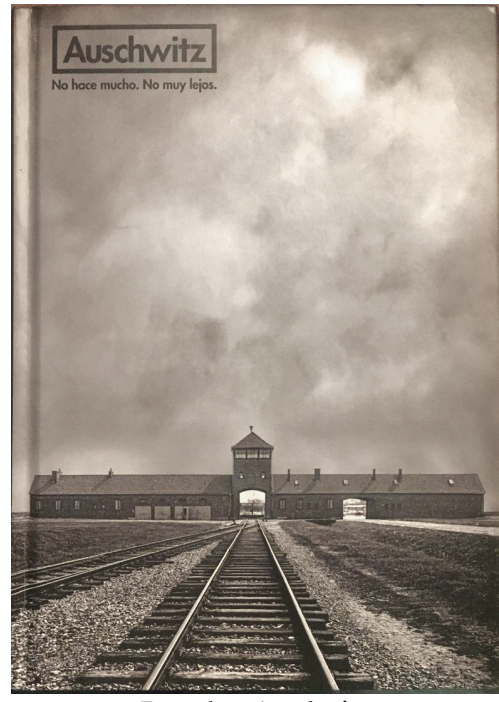

Entrada a Auschwitz
No es lícito olvidar, no es lícito callar. Si nosotros callamos, ¿quién hablará? ${ }^{1}$

A 73 años de haber sido liberado el campo de concentración de Auschwitz, hoy sigue siendo uno de los símbolos del Holocausto, de la ignominia y de la confirmación de la manifestación de la barbarie humana. Durante la Segunda Guerra Mundial, más de un millón de personas murieron solo por ser judíos, homosexuales, gitanos, romaníes o por tener una discapacidad mental o física; eran los indeseables, por el simple hecho de no formar parte de la raza aria.

"Aquellos que no recuerdan el pasado están condenados a repetirlo" 2 es la frase con la que abre la exposición itinerante Auschwitz. No hace mucho. No muy lejos, del Centro de Exposiciones Arte Canal en Madrid. Esta es la primera de las catorce sedes de Europa y Estados Unidos en las que esta exposición se presentará a lo largo de siete años. Curada por un grupo de expertos internacionales y coproducida por la empresa española Musealia y el Museo Auschwitz-Birkenau de Polonia, muestra por primera vez más de 600 objetos originales del campo de concentración, a través de un recorrido histórico y visual cargado de emotividad y respeto, en el que no solo se habla del pasado, sino también del presente, de lo que ocurrió y de lo que puede ocurrir. Los objetos exhibidos son las huellas del genocidio, la ausencia y la prueba material de los crímenes contra la humanidad: cartas, objetos personales, fotografías, testimonios, una lata de Zyklon B, una máscara de gas, una maleta, zapatos, las botas de un oficial nazi y un fragmento de un barracón de madera, recuerdan que el intento de aniquilar a hombres, mujeres y niños de toda Europa sucedió no hace mucho y no muy lejos de la sede de esta exhibición.

1 Primo Levi, Vivir para contar. Escribir tras Auschwitz, edición de Arnold I. Davidson, traducción Albert Fuentes, Revisión y nota final de Piero dal Bon, Alpha Decay, 2010, p. 30.

2 George de Santayana. 


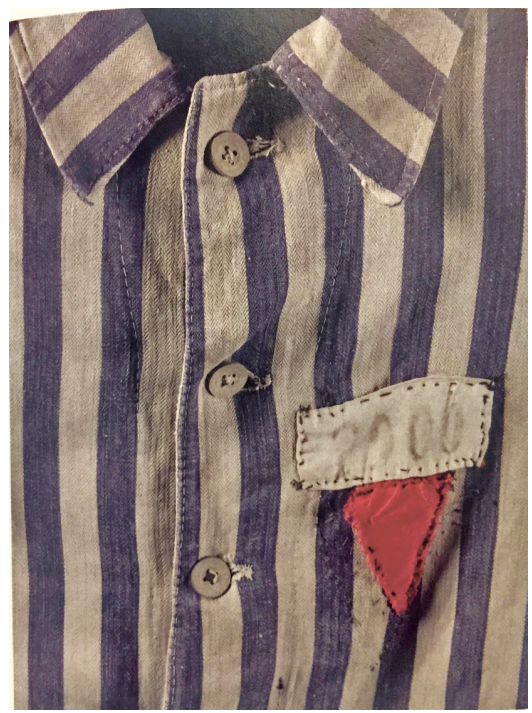

Camisa de recluso (1940-1944)

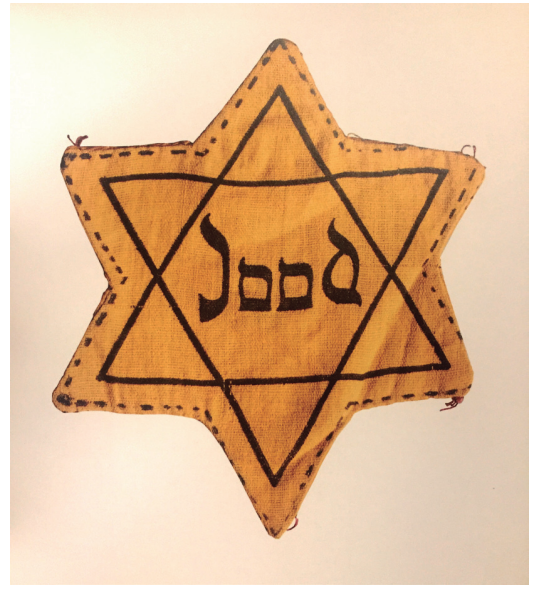

Distintivo amarillo con la palabra Jood (judío) que recibió Jenny Hanf, 1942

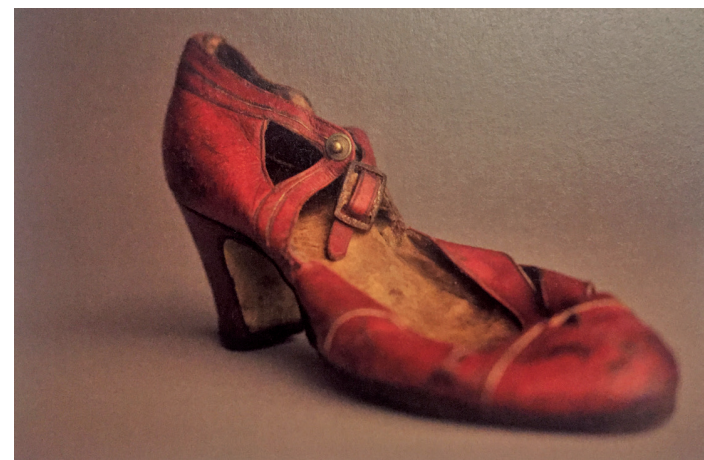

Zapato de vestir perteneciente a una deportada anónima. Colección del Museo Estatal de Auschwitz-Birkenau

La sala subterránea de 2500 metros cuadrados situada cerca de la Plaza de Castilla, fue dividida en dos partes en las que el espectador es guiado a través de un viaje en el tiempo al campo de concentración de Auschwitz, como prisión y como lugar de exterminio. Se revelan historias de personas y familias, de comunidades e instituciones, sobre una ideología que enseña a odiar, de actos de compasión y de amor, relatos de víctimas, héroes y culpables, y la historia de un continente marcado por las huellas de la memoria, la guerra y la muerte. Para poder comprender la importancia de la memoria, esa memoria que es la vida incrustada en la piel: el recuerdo que sigue implicado en el presente, en donde olvidar significa algo más. En este sentido, en la memoria colectiva de Auschwitz hay dos elementos que han adquirido gran importancia: el primero es el tren. En ellos deportaban a los judíos a los campos. No eran más que vagones de ganado de madera sin asientos, que apenas contaban con unas pequeñas ventanas. Eran cerrados por fuera herméticamente y, en ellos, cientos de personas sin espacio, viajaban durante días. Para tranquilizar a los pasajeros, los alemanes trataban

de engañar a las familias diciéndoles que, simplemente, los iban a trasladar a otras zonas de Europa o a campos de trabajo, sin imaginar lo que les esperaba a lo largo del viaje y cuál sería su destino. No les daban comida. Para beber solo había un cubo de agua al día para todos; un cubo era también todo lo que tenían para hacer sus necesidades. El olor era insoportable. Las temperaturas en verano eran asfixiantes; en invierno se congelaban. Era común que muchos murieran antes de llegar a los campos por inanición o enfermedades porque los alemanes no retiraban los cadáveres y tenían que viajar con ellos. En la entrada del Centro de Exposiciones Arte Canal, hay un vagón original y parte de una vía del tren que recibe a los visitantes, haciéndolos tomar consciencia del sufrimiento de los deportados en su camino hacia lo desconocido.

El segundo elemento de gran importancia son los zapatos. "Dos símbolos, la rueda y el calzado, propicios para el camino". Objetos que cuentan una historia y que han recorrido 
miles de kilómetros sin saber, a ciencia cierta, a quién le pertenecían o que secretos guardan y, 73 años después, forman parte de una exposición. ¿Quién era la mujer del zapato de tacón rojo? ¿En dónde vivía? ¿Cuántos años tenía el niño de la bota con un calcetín que se exhibe en una vitrina alumbrada con una luz tenue? ¿En dónde jugaba y de qué color eran sus ojos? Todas estas preguntas confirman que unos zapatos son más que un simple objeto; son el testimonio de una historia que debe ser contada y recordada. Aparentemente, muchos de los objetos exhibidos son ordinarios: unas gafas, unos zapatos o una manta se nos hacen muy familiares, pero, al mismo tiempo, esa familiaridad adquiere un significado diferente en los campos de concentración. Asociamos una manta con una cama cómoda y caliente, mientras que en Auschwitz, era un lugar frío e incómodo el que se compartía con enfermos y muertos al final de un largo día de trabajo. En este aspecto, Primo Levi, sobreviviente de Auschwitz, decía:

La muerte empieza por los zapatos: se han convertido, para la mayoría de nosotros en auténticos instrumentos de tortura que, después de las largas horas de marcha, ocasionan dolorosas heridas las cuales fatalmente se infectan. (...) Entonces lo único que le queda es el hospital: pero entrar en el hospital con el diagnóstico de dicke Füsse (pies hinchados) es extraordinariamente peligroso, porque es bien sabido por todos, y especialmente por los SS, que de este mal aquí es imposible curarse. ${ }^{3}$

Al reflexionar sobre lo que sucedió en los campos de la muerte nos damos cuenta de que casi no quedan sobrevivientes del Holocausto. Esas voces que luchan contra el silencio y su testimonio se han convertido en una obligación para evitar la desaparición del recuerdo, en un desahogo y en una importante válvula de escape para el dolor, de tal forma que las palabras y las imágenes son una necesidad imperiosa. Necesitamos memoria sobre lo sucedido en el pasado, y que esta se asocie con el presente. Como indicó el director del museo de Auschwitz, el Dr. Piotr M.A. Cywinski: "El mundo se mueve hoy en direcciones inciertas. Por eso necesitamos, cada vez más, apoyarnos en los fuertes pilares de nuestra memoria. Auschwitz es uno de esos pilares que no pueden ignorarse a la hora de crear un nuevo rostro para el mundo".

3 Primo Levi, Si esto es un hombre, Barcelona, El Aleph, 2006. 